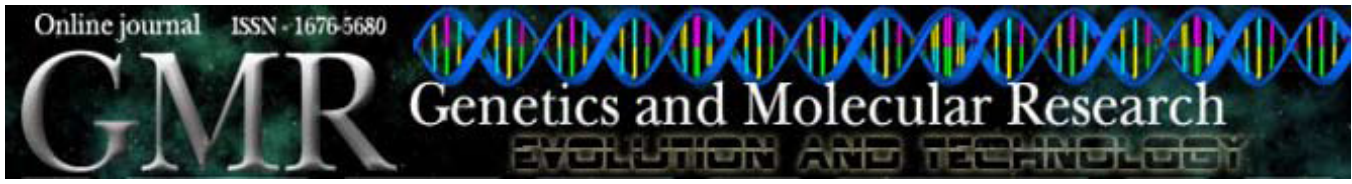

\title{
Molecular characterization and phylogenetic relationships among species of the genus Brycon (Characiformes: Characidae) from four hydrographic basins in Brazil
}

\author{
R.S.P. Antunes ${ }^{4}$, V.N. Gomes ${ }^{1,2}$, S.M.A.P. Prioli ${ }^{2,3}$, R.A. Prioli ${ }^{2}$, \\ H.F. Júlio Jr. ${ }^{2,3}$, L.M. Prioli ${ }^{2}$, C.S. Agostinho ${ }^{5}$ and A.J. Prioli ${ }^{2,3}$ \\ ${ }^{1}$ Programa de Pós-Graduação em Ecologia de Ambientes Aquáticos Continentais, \\ Universidade Estadual de Maringá, Maringá, PR, Brasil \\ ${ }^{2}$ Núcleo de Pesquisas em Limnologia, Ictiologia e Aqüicultura, \\ Universidade Estadual de Maringá, Maringá, PR, Brasil \\ ${ }^{3}$ Departamento de Biologia Celular e Genética, \\ Universidade Estadual de Maringá, Maringá, PR, Brasil \\ ${ }^{4}$ Departamento de Ciências, Universidade Estadual de Maringá, Maringá, PR, Brasil \\ ${ }^{5}$ Universidade Federal do Tocantins, Porto Nacional, TO, Brasil
}

Corresponding author: A.J. Prioli

E-mail: ajprioli@nupelia.uem.br

Genet. Mol. Res. 9 (2): 674-684 (2010)

Received December 18, 2009

Accepted January 25, 2010

Published April 13, 2010

DOI 10.4238/vol9-2gmr759

\begin{abstract}
Brycon is one of the main genera of Neotropical freshwater fish. In Brazil, Brycon species have been found in many hydrographic basins, such as the Amazon, Paraná, Paraguay, and AraguaiaTocantins basins. We examined the phylogenetic relationships among the species Brycon orbignyanus, B. hilarii, B. cf. pesu, B. cephalus, $B$. falcatus, and $B$. gouldingi, using mitochondrial and nuclear molecular markers. Specimens of B. orbignyanus were collected in the Paraná River. Specimens of $B$. hilarii were collected in the Manso River. Specimens of B. cephalus were obtained from a fish farm, and
\end{abstract}


specimens of $B$. cf. pesu, B. falcatus and B. gouldingi were sampled in the Araguaia-Tocantins basin. DNA extraction was carried out using the phenol/chloroform method. Molecular polymorphism studies of Brycon species were carried out with the inter-simple sequence repeat (ISSR) technique, using the total DNA of six specimens of each species. In DNA amplification of $B$. cf. pesu, eight specimens were used. The partial sequence of mitochondrial cytochrome $b$ was amplified by PCR. The PCR products were used directly in sequencing reactions. Each ISSR primer produced from 7 to 14 scorable and reproducible bands. The (GGAC) ${ }_{3} \mathrm{~A}$ and $(\mathrm{GGAC})_{3} \mathrm{C}$ primers produced the greatest number of species-specific bands. A 264-bp fragment, corresponding to the partial region of mitochondrial DNA cytochrome b, was sequenced and used for analysis. According to the phylogenetic tree obtained from the data, these Brycon species can be divided into two clades: one comprised only $B$. cf. pesu, and the second comprised the remaining Brycon species. We conclude that ISSR primers can be used for the identification of species-specific bands in fish, such as Brycon spp.

Key words: Brycon; Phylogenetic relationships; mtDNA cytochrome b; Inter-simple sequence repeat

\section{INTRODUCTION}

The genus Brycon belongs to the Bryconinae subfamily and is considered to be one of the main Neotropical fishes of freshwater systems. It comprises more than 40 species (Lima, 2003), widely distributed in Central and South America. Many of them represent important fishery resources. In Brazil, species of Brycon have been found in the majority of hydrographic basins, such as the Amazon, Paraná, Paraguay, and Araguaia-Tocantins basins. The present study included six species distributed in the basins mentioned: Brycon orbignyanus, B. hilarii, B. cf. pesu, B. cephalus, B. falcatus, and B. gouldingi.

Brycon orbignyanus (Valenciennes, 1850), also called "piracanjuba", is native to the Paraná River Basin. It is a big and migratory fish, which is of great economic importance. Populations of this species are abundant in the upper Paraná River basin and in its main tributaries, such as Grande, Tietê and Paranapanema Rivers. However, currently, $B$. orbignyanus is on the critically threatened species list (Machado, 2005). The reduction of their populations has been related to the construction of hydroelectric dams, destruction of riparian areas and predatory fishing.

Brycon hilarii (Valenciennes, 1850), known as "piraputanga", is a rheophylic fish, of great value for commercial fishing. It occurs in the Middle Paraná and Paraguay River basins. It has omnivorous habits, living in regions of both rapidly and slowly flowing waters, under fruitful trees and near aquatic plants.

Brycon cf. pesu Müller \& Troschel, 1845 is distributed in the coastal basins of northeast South America, Orinoco River basin, and Amazon and Araguaia-Tocantins basins (Lima, 2003). It is a small fish, found in sandy and rocky areas in rapidly flowing waters and habitu- 
ally feeds at river banks, mainly on terrestrial insects.

Brycon cephalus (Günther, 1869) is native to the Amazon basin and is also known as "matrinxã". It is widely exploited in commercial activities (Izel et al., 2004).

Brycon falcatus Müller \& Troschel, 1844 is an omnivorous species distributed in Guyana, Suriname and French Guiana Rivers, and the Amazon, Orinoco and Araguaia-Tocantins River basins.

Brycon gouldingi (Lima, 2004) is endemic to the Araguaia-Tocantins basin, where it feeds on fruits and insects.

The six species of Brycon cited are important components of the Brazilian ichthyofauna and are of importance in commercial fishing, aquatic biodiversity and for maintaining the equilibrium of food chains in Brazilian freshwater ecosystems. However, some species, such as those found in the Araguaia-Tocantins basin, have been scarcely studied, and little is known about their biology and genetics. Besides, there are no reported phylogenetic studies involving the six species mentioned.

The possibility to quantify genetic variability by the direct analysis of polymorphism of DNA fragments has stimulated the advance of population genetics and the genetics of evolutionary processes. DNA polymorphism, associated with morphological and ecological studies, has been useful in demonstrating ecological genetics diversity and the genetics of the evolution process in species and subspecies. DNA amplification by PCR (polymerase chain reaction) and the sequencing of DNA fragments are the main methodologies. ISSR (inter-simple sequence repeat) method is based on amplification of DNA fragments by means of a single primer composed of a short microsatellite sequence with one to four degenerate nucleotides anchored at the 5 ' or 3' end, as described by Gupta et al. (1994). ISSR molecular markers (Schulz et al., 2004; Maltagliati et al., 2006; Pazza et al., 2007) and mitochondrial DNA (mtDNA) sequences have been revealed as important tools in studies regarding the genetic structure of populations, phylogeographic relations and phylogenetic reconstruction in fish (Reeves and Bermingham, 2006; Haponski and Stepien, 2008; Almada et al., 2009; Kawamura et al., 2009).

The aim of the present article was to study the phylogenetic relationships among the species B. orbignyanus, B. hilarii, B. cf. pesu, B. cephalus, B. falcatus, and B. gouldingi, using mitochondrial and nuclear molecular markers.

\section{MATERIAL AND METHODS}

\section{Biological material}

Specimens of $B$. orbignyanus were collected in the Paraná River, in the region of Guaíra. Specimens of $B$. hilarii were collected in the Manso River. Specimens of $B$. cephalus were obtained from a fish farm, and specimens of $B$. cf. pesu, B. falcatus and $B$. gouldingi were sampled in the Araguaia-Tocantins basin. Specimens of $B$. $c f$. pesu were collected in the fish ladder of the Lajeado Hydroelectric Plant ( $9^{\circ} 46^{\prime} \mathrm{S} 48^{\circ} 21^{\prime} \mathrm{W}$ ), built on the Tocantins River, and in the Palmas River, its tributary. Specimens of B. falcatus and $B$. goulding $i$ were collected in the fish ladder of the Lajeado Hydroelectric Plant (Figure 1). 


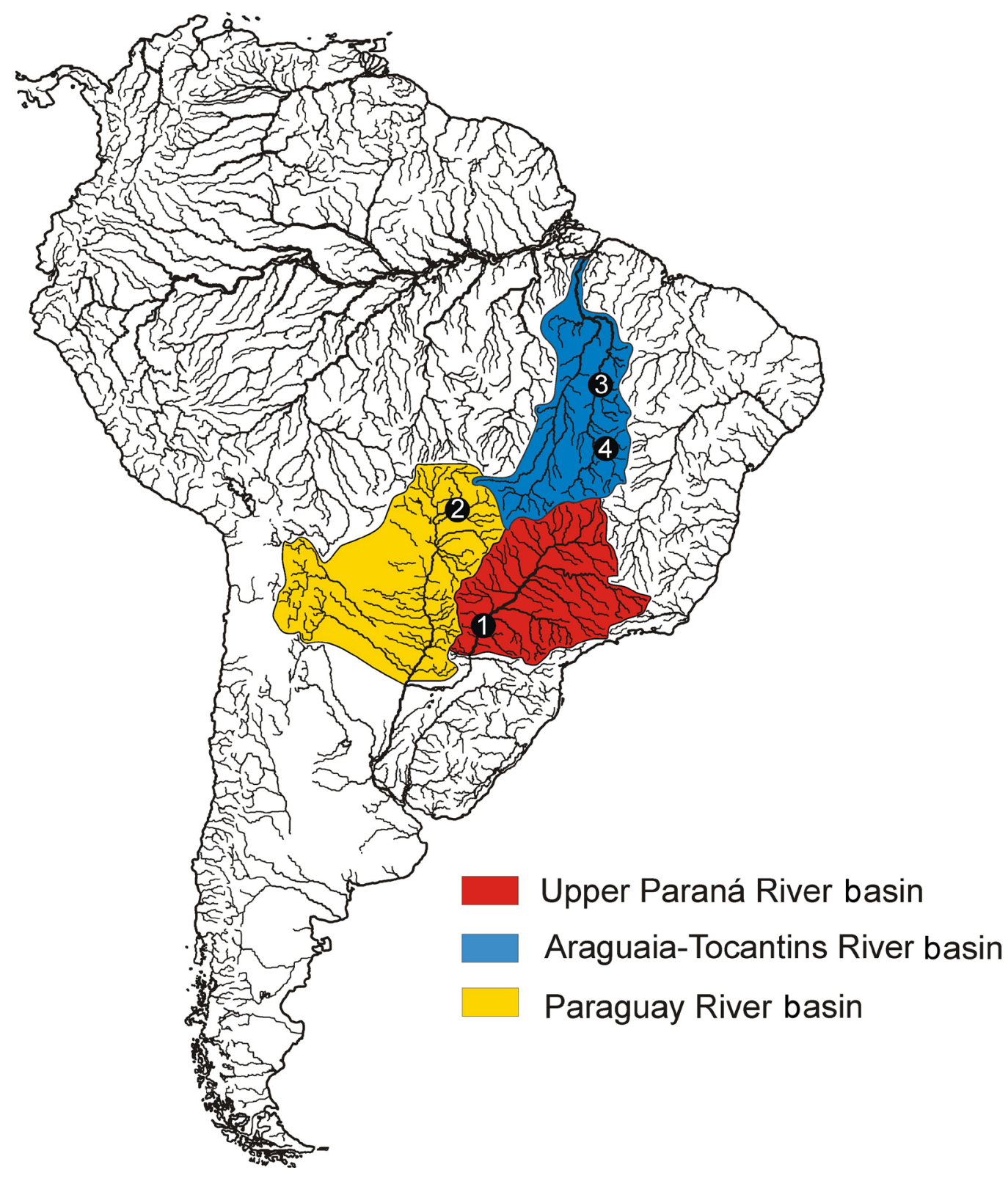

Figure 1. Araguaia-Tocantins basin. 1 = Guaíra; 2 = Manso River; 3 = Lajeado Hydroelectric Plant fish ladder; 4 = Palmas River. 


\section{DNA extraction}

DNA extraction was carried out using the phenol/chloroform method (Monesi et al., 1998). Samples of muscle tissue were macerated in liquid nitrogen. Samples were homogenized in $500 \mu \mathrm{L}$ TH buffer $(10 \mathrm{mM}$ Tris- $\mathrm{HCl}, 60 \mathrm{mM} \mathrm{NaCl}, 10 \mathrm{mM}$ EDTA, $5 \%$ sucrose, 0.15 $\mathrm{mM}$ spermine, and $0.15 \mathrm{mM}$ spermidine) plus $500 \mu \mathrm{L}$ PS buffer (Tris- $0.2 \mathrm{M} \mathrm{HCl}, 30 \mathrm{mM}$ EDTA, $2 \%$ SDS, and $5 \%$ sucrose $)$ and $5 \mu \mathrm{L}$ proteinase $\mathrm{K}(20 \mu \mathrm{g} / \mu \mathrm{L})$, and then were incubated in a shaking water bath at $37^{\circ} \mathrm{C}$ for approximately $1 \mathrm{~h}$. Next, DNA was purified through washes with phenol/chloroform (1:1) and chloroform. DNA was then precipitated using saline $(0.2 \mathrm{M}$ $\mathrm{NaCl})$ and chilled ethanol. The precipitate was submitted to several centrifugations with 70 and $100 \%$ ethanol, and finally resuspended in TE ( $1 \mathrm{mM}$ Tris, $0.1 \mathrm{mM}$ EDTA) containing RNase. DNA of all samples was later quantified on a $0.8 \%$ agarose gel stained with ethidium bromide $(20 \mu \mathrm{g} / 100 \mathrm{~mL})$. DNA samples were quantified by comparison with known quantities of phage $\lambda$ DNA (Invitrogen Life Technologies ${ }^{\mathrm{TM}}$, Carlsbad, CA, USA), on agarose gel (0.8\%) stained with ethidium bromide $(20 \mu \mathrm{g} / 100 \mathrm{~mL})$.

\section{Inter-simple sequence repeat and data analysis}

ISSR primers composed of the tetranucleotide repeats $(\mathrm{AACC})_{4},(\mathrm{GGAC})_{3} \mathrm{C}$, $(\mathrm{GGAC})_{3} \mathrm{~A},(\mathrm{GGAC})_{3} \mathrm{~T}$, and $(\mathrm{GGAC})_{4}$ were selected for analysis. The PCR technique was used for the amplification of the total DNA of six specimens of each species. In DNA amplification of $B$. cf. pesu, eight specimens were used. The amplification method was in accordance with the protocol described by Fernandes-Matioli et al. (2000). In each experiment, a sample without template DNA was included as a negative control. Aliquots $(10 \mu \mathrm{L})$ of PCR amplification products were applied on $1.4 \%$ agarose gels stained with ethidium bromide $(20 \mu \mathrm{g} / 100$ $\mathrm{mL}$ ), and separated by electrophoresis in TBE buffer (Tris-borate) at $5 \mathrm{~V} / \mathrm{cm}$ for 3-4 h. Amplified fragments were visualized under UV irradiation and photographed for later analysis. Sizes of fragments were estimated by comparison with a standard 100-bp ladder (Invitrogen).

The matrix of Nei and Li similarity means within and among Brycon species was obtained from ISSR data, using the Mantel-Struct 1.0 program (Miller, 1999). The principal coordinate plot was constructed from Nei and Li distances with the FAMD program (Schlüter and Harris, 2006).

\section{Mitochondrial DNA and data analysis}

PCR amplifications of a partial cytochrome $b$ sequence were performed with the primers H15149 5'-CCCCTCAGAATGATATTTGTCCTCA-3' and L14841 5'-CCATCCAA CATCTCAGCATGATGAAA-3' (Kocher et al., 1989), as described by Prioli et al. (2002). Five samples of $B$. hilarii, B. orbignyanus and B. cephalus were analyzed. Six specimens of $B$. cf.pesu and four specimens of $B$. falcatus were sequenced. The sequencing of $B$. gouldingi specimens was not successful, and they were thus excluded from analysis. Amplifications were carried out in $25-\mu \mathrm{L}$ reaction mixtures containing Tris- $\mathrm{KCl}$ buffer $(20 \mathrm{mM}$ Tris- $\mathrm{HCl}, \mathrm{pH} 8.4$, and $50 \mathrm{mM}$

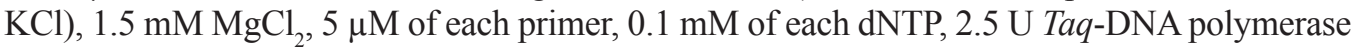
(Invitrogen), $30 \mathrm{ng}$ genomic DNA and deionized autoclaved water to make the volume up to 25 $\mu \mathrm{L}$. Amplification reactions were performed with a regime of $94^{\circ} \mathrm{C}$ for $4 \mathrm{~min}, 50^{\circ} \mathrm{C}$ for $30 \mathrm{~s}$ and $72^{\circ} \mathrm{C}$ for $1 \mathrm{~min}$ and $30 \mathrm{~s}$, and then 40 cycles of $30 \mathrm{~s}$ at $94^{\circ} \mathrm{C}, 30 \mathrm{~s}$ at $56^{\circ} \mathrm{C}, 1 \mathrm{~min}$ and $30 \mathrm{~s}$ at $72^{\circ} \mathrm{C}$, 
followed by a final cycle of $1 \mathrm{~min}$ at $94^{\circ} \mathrm{C}, 1 \mathrm{~min}$ at $56^{\circ} \mathrm{C}$ and $7 \mathrm{~min}$ at $72^{\circ} \mathrm{C}$. PCR products were checked on $1 \%$ agarose gels. The DNA samples (of approximately $50 \mathrm{ng}$ ) amplified in each PCR were used directly in sequencing reactions with BigDye Terminator Cycle Sequencing, in an ABI-3100 automatic sequencer (Perkin Elmer), according to manufacturer instructions.

The sequences were aligned with the MEGA 4.0 program (Tamura et al., 2007), and edited with the BIOEDIT program (Hall, 1999). A partial cytochrome b sequence of $B$. hilarii (AY 791370) was included in the analysis. Based on the study of Margarido and Galetti-Junior (1999), Salminus brasiliensis (AY 791438) was selected as the outgroup.

The evolutionary model was selected using PAUP 4.0 (Swofford, 2002) and MODELTEST 3.7 programs (Posada and Crandall, 1998). Akaike Information Criterion with correction and Bayesian Information Criterion procedures were performed.

The evolutionary model selected was also used to estimate the genetic distances and to construct a dendrogram with the neighbor-joining algorithm, based on 10,000 replicates. The phylogenetic tree was obtained with the MEGA 4.0 program (Tamura et al., 2007).

\section{RESULTS}

\section{Inter-simple sequence repeat}

Of the total of five ISSR primers, four yielded species-specific ISSR profiles in at least one of the species studied (Figure 2). The (GGAC) ${ }_{3} \mathrm{~T}$ primer did not produce clear amplifications and was excluded from analyses. The amplified fragments varied in length from 300 to $1900 \mathrm{bp}$ (Table 1). Each primer used produced from 7 to 14 scorable and reproducible bands for 43 polymorphic loci. Around 37\% of the bands detected were species-specific. The $(\mathrm{GGAC})_{3} \mathrm{~A}$ and $(\mathrm{GGAC})_{3} \mathrm{C}$ primers produced the greatest number of species-specific bands. GGAC) ${ }_{3} \mathrm{C}$ primer yielded 5 species-specific bands in 6 species of Brycon analyzed.

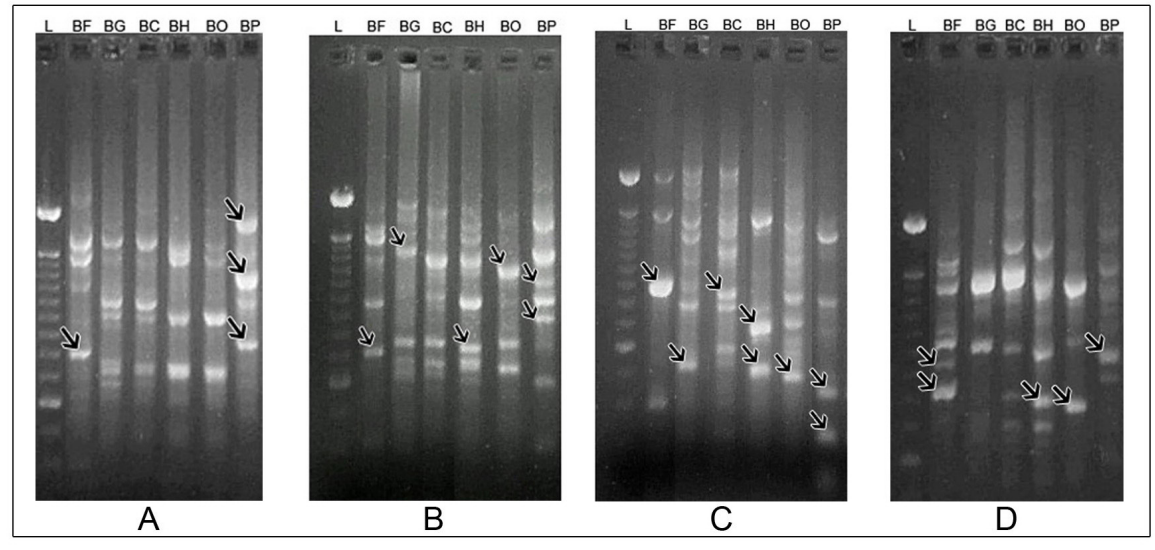

Figure 2. Electrophoretic profiles of the inter-simple sequence repeat of six species of Brycon. A. Primer (AACC) . B. Primer $(\mathrm{GGAC})_{3}$ A. C. Primer $(\mathrm{GGAC})_{3}$ C. D. Primer $(\mathrm{GGAC})_{4}$. L = Molecular weight marker fragments $(100-$ bp ladder, Invitrogen Life Technologies, Carlsbad, $\mathrm{CA}, \mathrm{USA}) ; \mathrm{BF}=$ Brycon falcatus; $\mathrm{BG}=B$. gouldingi; $\mathrm{BC}=B$. cephalus; $\mathrm{BH}=B$. hilarii; $\mathrm{BO}=B$. orbignyanus; $\mathrm{BP}=B$. cf. pesu. Arrows indicate species-specific bands. 
Table 1. Approximate length in bp of inter-simple sequence repeat fragments of Brycon falcatus, B. gouldingi, B. cephalus, B. hilarii, B. orbignyanus, and B. cf. pesu specimens.

\begin{tabular}{|c|c|c|c|c|c|c|c|c|c|c|c|c|c|c|}
\hline \multicolumn{15}{|l|}{ Primer $(\mathrm{GGAC})_{4}$} \\
\hline Fragments ( bp) & 1650 & 1400 & 1350 & 1150 & 1050 & 920 & 800 & & & & & & & \\
\hline B. falcatus & - & - & $+\mathrm{m}$ & - & $+\mathrm{m}$ & $+\mathrm{p}$ & $+\mathrm{m}$ & & & & & & & \\
\hline B. gouldingi & - & - & $+\mathrm{m}$ & - & $+\mathrm{m}$ & - & - & & & & & & & \\
\hline B. cephalus & $+\mathrm{m}$ & $+\mathrm{m}$ & - & - & $+\mathrm{p}$ & - & $+\mathrm{m}$ & & & & & & & \\
\hline B. hilarii & $+\mathrm{m}$ & $+\mathrm{m}$ & - & - & $+\mathrm{p}$ & - & $+\mathrm{m}$ & & & & & & & \\
\hline B. orbignyanus & - & $+\mathrm{m}$ & - & - & - & - & $+\mathrm{m}$ & & & & & & & \\
\hline B. cf. pesu & - & - & - & $+\mathrm{p}$ & $+\mathrm{m}$ & $+\mathrm{p}$ & - & & & & & & & \\
\hline \multicolumn{15}{|l|}{ Primer $(\mathrm{AACC})_{4}$} \\
\hline Fragments ( bp) & 2000 & 1750 & 1700 & 1400 & 1250 & 1050 & 900 & 850 & 800 & 720 & & & & \\
\hline B. falcatus & - & - & $+\mathrm{m}$ & $+p$ & $+\mathrm{p}$ & - & - & - & $+\mathrm{m}$ & - & & & & \\
\hline B. goulding $i$ & - & $+\mathrm{p}$ & - & $\begin{array}{r}\mathrm{p} \\
+\mathrm{p}\end{array}$ & - & $+\mathrm{p}$ & - & - & - & $+\mathrm{m}$ & & & & \\
\hline B. cephalus & - & $+\mathrm{r}$ & - & - & - & $\begin{array}{r}r \\
+\mathrm{p}\end{array}$ & - & - & - & $+\mathrm{m}$ & & & & \\
\hline B. hilarii & - & $+\mathrm{p}$ & $+\mathrm{m}$ & $+\mathrm{m}$ & - & - & - & - & - & $+\mathrm{m}$ & & & & \\
\hline B. orbignyanus & - & $+\mathrm{m}$ & $+\mathrm{m}$ & $+\mathrm{m}$ & - & - & - & - & - & $+\mathrm{m}$ & & & & \\
\hline B. cf. pesu & $+\mathrm{m}$ & - & - & - & $+\mathrm{m}$ & - & $+\mathrm{p}$ & $+\mathrm{m}$ & - & - & & & & \\
\hline \multicolumn{15}{|l|}{ Primer $(\mathrm{GGAC})_{3} \mathrm{C}$} \\
\hline$\overline{\text { Fragments ( bp) }}$ & 2300 & 1200 & 850 & 800 & 750 & 650 & 600 & 570 & 550 & 520 & 470 & 350 & & \\
\hline B. falcatus & - & - & $+\mathrm{m}$ & - & - & - & - & - & - & - & - & - & & \\
\hline B. gouldingi & $+\mathrm{m}$ & - & - & $+\mathrm{p}$ & $+\mathrm{m}$ & - & - & $+\mathrm{p}$ & - & - & - & - & & \\
\hline B. cephalus & $+\mathrm{m}$ & $+\mathrm{m}$ & - & $+\mathrm{m}$ & $+\mathrm{m}$ & - & $+\mathrm{p}$ & - & - & - & - & - & & \\
\hline B. hilarii & - & - & - & - & $+\mathrm{m}$ & $+\mathrm{m}$ & - & - & $+\mathrm{m}$ & - & - & - & & \\
\hline B. orbignyanus & - & $+\mathrm{p}$ & - & $+\mathrm{p}$ & - & - & $+\mathrm{p}$ & - & - & $+\mathrm{m}$ & - & - & & \\
\hline B. cf. pesu & - & - & - & $+\mathrm{p}$ & - & $+\mathrm{p}$ & - & - & - & - & $+\mathrm{p}$ & $+\mathrm{m}$ & & \\
\hline \multicolumn{15}{|l|}{ Primer $(\mathrm{GGAC})_{3} \mathrm{~A}$} \\
\hline Fragments ( bp) & 1900 & 1800 & 1600 & 1500 & 1350 & 1220 & 1150 & 1100 & 950 & 900 & 750 & 720 & 700 & 650 \\
\hline B. falcatus & $+\mathrm{m}$ & - & $+\mathrm{m}$ & $+\mathrm{m}$ & - & - & - & $+\mathrm{p}$ & $+\mathrm{m}$ & - & - & - & $+\mathrm{m}$ & - \\
\hline B. gouldingi & - & $+\mathrm{m}$ & - & - & $+\mathrm{m}$ & - & - & - & - & - & - & $+\mathrm{m}$ & - & $+\mathrm{m}$ \\
\hline B. cephalus & - & - & - & - & - & $+\mathrm{m}$ & - & $+\mathrm{m}$ & - & - & - & $+\mathrm{m}$ & - & $+\mathrm{m}$ \\
\hline B. hilarii & - & - & - & $+\mathrm{p}$ & - & $+\mathrm{p}$ & - & $+\mathrm{m}$ & - & - & - & $+\mathrm{m}$ & - & $+\mathrm{m}$ \\
\hline B. orbignyanus & - & - & - & - & - & $+\mathrm{r}$ & - & $+\mathrm{p}$ & - & - & $+\mathrm{m}$ & - & - & $+\mathrm{m}$ \\
\hline B. cf. pesu & - & $+\mathrm{m}$ & - & - & $+\mathrm{m}$ & - & $+\mathrm{p}$ & - & $+\mathrm{p}$ & $+\mathrm{p}$ & $+\mathrm{m}$ & - & - & - \\
\hline
\end{tabular}

Presence or absence of a DNA fragment on the agarose gel is indicated by + and -, respectively. The DNA fragment present in a species can be monomorphic $(\mathrm{m})$ or polymorphic $(\mathrm{p})$.

B. gouldingi and B. cephalus exhibited the most similar ISSR electrophoretic profile, followed by $B$. hilarii and $B$. orbignyanus. The most genetically diverse species, according to the ISSR data, were B. falcatus and B. cf. pesu.

The table of similarity means (Table 2 ) shows that the divergence among individuals of the same species is lower than that for individuals of different species. The principal coordinate plot and the dendrogram obtained from ISSR data (Figures 3 and 4) separated the six species studied. Brycon hilarii and B. orbignyanus are the most closely related, whereas $B$. $c f$. pesu is the most divergent.

Table 2. Nei and Li similarity means based on inter-simple sequence repeat molecular markers, within (diagonal)
and among (lower left) species of Brycon.
\begin{tabular}{lcccccc}
\hline Species & B. falcatus (1) & B. gouldingi (1) & B. cephalus (2) & B. hilarii (3) & B. orbignyanus (4) & B. cf. pesu (1) \\
\hline B. falcatus (1) & 0.0660 & & & & & \\
B. gouldingi (1) & 0.8027 & 0.0786 & & & & \\
B. cephalus (2) & 0.7808 & 0.4626 & 0.0422 & & & \\
B. hilari (3) & 0.6824 & 0.5463 & 0.3690 & 0.0735 & 0.0814 & \\
B. orbignyanus (4) & 0.7434 & 0.6511 & 0.3970 & 0.4125 & 0.1693 \\
B. c. pesu (1) & 0.7434 & 0.7334 & 0.9257 & 0.9001 & 0.9113 & 0.16 \\
\hline
\end{tabular}

1 = Araguaia-Tocantins River basin; 2 = Amazon River basin; 3 = Paraguay River basin; 4 = Paraná River basin. 


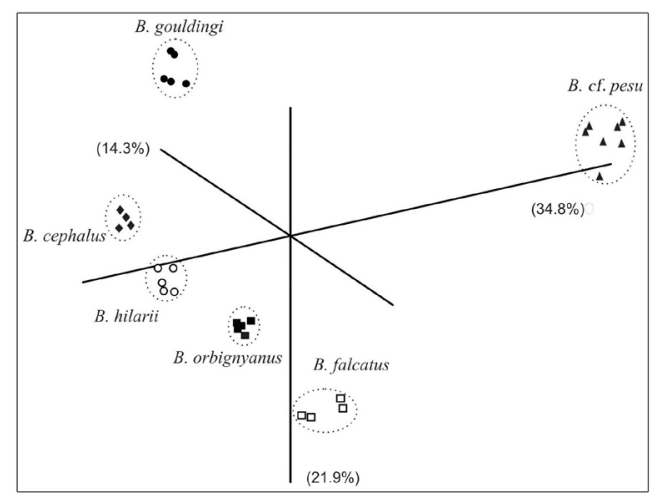

Figure 3. Principal coordinate plot of Brycon species constructed from the Nei and Li distances obtained with intersimple sequence repeat markers.

\section{Mitochondrial DNA}

A fragment of $264 \mathrm{bp}$, corresponding to the partial region of the mtDNA cytochrome b, was sequenced and used for analysis. Sixty-eight polymorphic nucleotide sites were identified (Table 3), corresponding to around $25 \%$ of the total number of sequences analyzed. Tamura and Nei + I was the evolutionary model selected by PAUP 4.0 and MODELTEST 3.7 programs. Based on this model, the neighbor joining dendrogram was obtained. A similar dendrogram was also obtained from ISSR data and was compared with the dendrogram generated from cytochrome b data (Figure 4).

\begin{tabular}{|c|c|c|c|}
\hline Specimen & Haplotype & Identification & 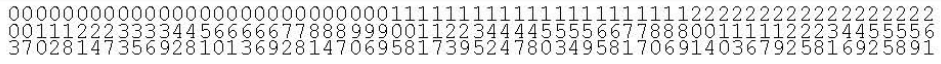 \\
\hline 4-BF03 & apl-Bfc1 & B. falcatus & АTTTCACTCATCTTTAACCTTCGTTACTCTCCTCCCACCGCGCACTCCATGTAAACAACAGTTGTTTA \\
\hline 4-BF05 & Hapl-Bfc1 & B. falcatus & ... \\
\hline 4-BF06 & Hapl-Bfc1 & B. falcatus & \\
\hline 4-BF07 & Hapl-Bfc1 & B. falcatus & \\
\hline 2-BH06 & Hapl-Bhil & B. hilarii & 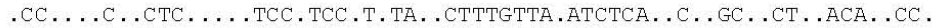 \\
\hline AY791370 & Hapl-Bhi2 & B. hilarii & 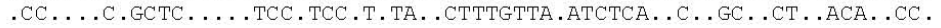 \\
\hline 2-BH03 & Hapl-Bhi3 & B. hilarii & 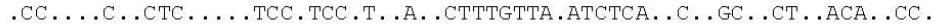 \\
\hline 2-BH01 & Hapl-Bhi3 & B. hilarii & 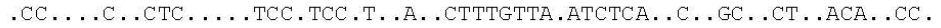 \\
\hline $3-\mathrm{BC} 05$ & Hapl-Bcp1 & B. cephalus & 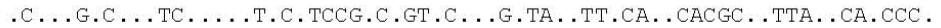 \\
\hline $3-\mathrm{BC} 06$ & Hapl-Bcp1 & B. cephalus & 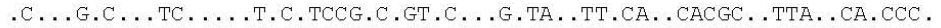 \\
\hline $3-\mathrm{BC} 08$ & Hapl-Bcp1 & B. cephalus & 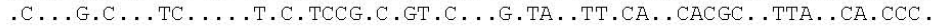 \\
\hline $1-\mathrm{BO} 22$ & Hapl-Bob1 & B. orbignyanus & 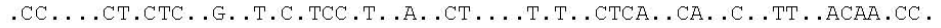 \\
\hline $1-\mathrm{BO} 25$ & Hapl-Bob2 & B. orbignyanus & 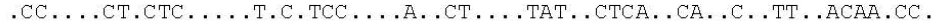 \\
\hline $1-\mathrm{BO} 26$ & Hapl-Bob3 & B. orbignyanus & 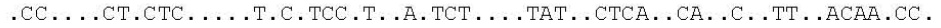 \\
\hline 4-BP11 & Hapl-Bps1 & B. cf pesu & TCTCA.TC ..C.CCC.GT.CCTACC.TC.A.T..T. .T.ATCTC.TGCAC .TT.CATACACCACC \\
\hline 4-BP02 & Hapl-Bps1 & B. cf pesu & TCTCA.TC ..C.CCC.GT.CCTACC.TC.A.T..T. .T. ATCTC.TGCAC .TT.CATACACCACC \\
\hline 4-BP10 & Hapl-Bps1 & B. сf pesu & TCTCA.TC . C.CCC.GT.CCTACC.TC.A.T. .T. . T. ATCTC.TGCAC .TT.CATACACCACC \\
\hline 4-BP15 & Hapl-Bps1 & B. cf pesu & TCTCA.TC ..C.CCC.GT.CCTACC.TC.A.T..T. .T.ATCTC.TGCAC .TT.CATACACCACC \\
\hline 4-BP20 & Hapl-Bps1 & B. сf pesu & TCTCA.TC ..C.CCC.GT.CCTACC.TC.A.T. .T. .T. АTCTC.TGCAC . TT.CATACACCACC \\
\hline 4-BP19 & Hapl-Bps1 & B. сf реsu & TCTCA.TC ..C.CCC.GT.CCTACC.TC.A.T..T...T.ATCTC.TGCAC .TT.CATACACCACC \\
\hline AY791370 & Hapl-Bhi3 & B. hilarii & 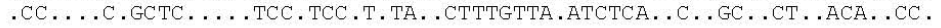 \\
\hline
\end{tabular}

The places sampled are indicated by the first number in the identification of each species. 1 = Paraná River basin; $2=$ Paraguay River basin; $3=$ Amazon basin; $4=$ Araguaia-Tocantins River basin. Haplotypes: Hapl-Bfc $=B$. falcatus; Hapl-Bhi = B. hilarii; Hapl-Bcp = B. cephalus; Hapl-Bob = B. orbignyanus; Hapl-Bps = B. cf. pesu. Dots indicate identity. Polymorphic nucleotide sites are shown for specimen 4-BF03. 
According to the phylogenetic tree obtained from cytochrome b sequences, the Brycon species studied were separated into two clades. One comprised only $B$. $c f$. pesu and the second comprised the other species: B. hilarii, B. orbignyanus, B. cephalus, and B. falcatus.

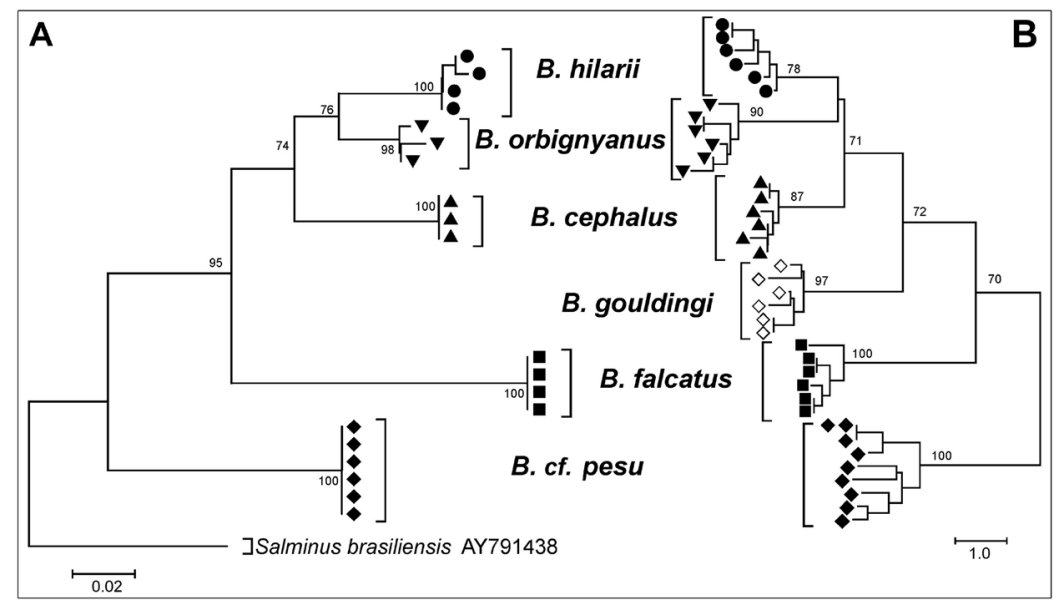

Figure 4. Neighbor-joining dendrograms constructed from the Tamura and Nei + I distance matrix among the mitochondrial cytochrome $\mathrm{b}$ sequences (A) and from inter-simple sequence repeat markers based on Nei and $\mathrm{Li}$ distances (B) of the Brycon species. Numbers above branches are bootstrap values, as based on 10,000 replicates.

\section{DISCUSSION}

The data obtained by the analysis of cytochrome $b$ sequences corroborated the results determined by the ISSR data. The phylogenetic trees constructed from ISSR and cytochorome $\mathrm{b}$ data produced the same clades. Brycon gouldingi, studied only with ISSR markers, occupies an intermediary position in evolutionary terms, when compared with the other Brycon species.

The phylogenetic tree obtained from cytochrome b sequences separated the Brycon species into two clades. One comprised only B. cf. pesu, the most basal group. In other words, the bifurcation, which originated this species, is older than the other group of Brycon species analyzed. The second clade is composed of the other species: B. hilarii, B. orbignyanus, B. cephalus, and $B$. falcatus. Besides, the results demonstrated that the species of the genus Brycon belong to a monophyletic group. Phylogenetic studies with B. pesu, B. hilarii, B. orbignyanus, and other Brycon species, based on the mitochondrial gene 16S rRNA, also supported the monophyletic status of the Brycon species, although considered the paraphyletic status of the genus (Hilsdorf et al., 2008).

The phylogenetic relationships among the Brycon species analyzed could be related to their geographic distributions, as well as to their morphologic similarity. The Paraná River and Paraguay River basins, along with the Uruguay River, belong to the Prata River basin. The Paraguay River is the main tributary of the Paraná River, where individuals of $B$. orbignyanus were obtained. The Manso River, where $B$. hilarii specimens were collected, joins in its river mouth with the Cuiabazinho River to form the Cuiabá River (Neto et al., 1993). This river, in turn, is one of the main tributaries of the Paraguay River.

Among the four basins where Brycon species were obtained, the most geopraphically close are the Paraná River and the Paraguay River basins. Therefore, B. orbignyanus 
and $B$. hilarii, belonging to these basins, are more closely related than the other species. This is demonstrated by the dendrogram, because both species have their origins in the same bifurcation. The Manso River, as well as Paraná River, in some parts of their courses, have characteristics of a plain river (Neto et al., 1993). Such environments, with similar characteristics, allowed the origin of species with similar habits and morphological features, such as $B$. hilarii and B. orbignyanus. Hilsdorf et al. (2008) studied species of the genus Brycon with the mitochondrial gene 16S rRNA and also demonstrated that $B$. hilarii and B. orbignyanus are sister groups.

The Amazon and the Araguaia-Tocantins basins are interconnected. The Amazon ba$\sin$ is composed of the Amazon River and its tributaries, while the Araguaia-Tocantins basin is composed of the Tocantins and Araguaia Rivers, and their tributaries. The Tocantins River arises in Goiás State, passing by Tocantins, Maranhão and Pará States, until arriving in the mouth of the Amazon River, where it empties its water. B. cf. pesu and B. falcatus belong to the Araguaia-Tocantins basin and are also found in the Amazon basin.

The analyses of mtDNA cytochrome $\mathrm{b}$ data demonstrated that $B$. $c f$. pesu and $B$. falcatus, within the group analyzed, have origins in older clades. Both species are very morphologically diverse, since $B$. $c f$. pesu is a small fish while $B$. falcatus is a big fish. Besides, the phylogenetic tree shows that the distance between $B$. falcatus and the clade comprised of large-sized species, $B$. orbignyanus, $B$. hilarii and $B$. cephalus, is smaller than the distance between $B$. falcatus and $B$. cf. pesu. However, the phylogenetic analysis indicates that $B$. falcatus is more closely related to the large-sized species than to $B$. $c f$. pesu, a small-sized fish.

According to the results, B. cephalus and B. hilarii diverged from a common ancestor, that branched out into two lineages: the older originated $B$. cephalus, and the most recent was divided into two branches. One originated $B$. orbignyanus and the second originated $B$. hilarii. $B$. cephalus is restricted to the Amazon basin and is closely related to B. orbignyanus and $B$. hilarii, since the Amazon basin is also connected with the Paraná-Paraguay basin. Besides, the three species mentioned are large and have similar external morphology and habits.

Based on the results obtained in the present study, we can conclude that ISSR primers are efficient in detecting species-specific loci in fish, and thus, they may be used as tools to assist in the identification of species, as reported by other authors (Schulz et al., 2004; Maltagliati et al., 2006). The application of these markers is important in identifying species, as well as detecting genetic variability, in order to preserve threatened species and to reestablish stocks with low genetic diversity for conservation purposes.

In the Brycon species analyzed here, the $(\mathrm{GGAC})_{3} \mathrm{~A}$ and $(\mathrm{GGAC})_{3} \mathrm{C}$ primers were the most effective in discriminating species-specific bands.

Among the species studied, B. hilarii and B. orbignyanus are the most closely related. $B$. $c f$. pesu is of the oldest origin and greatest genetic distance. Both inferences were corroborated by nuclear and mitochondrial markers. The phylogenetic relationships found among Brycon species can be associated with geographic distribution, as well as with the morphology of the species.

\section{ACKNOWLEDGMENTS}

The authors are grateful to Dr. Ubiratan Piovezan and Dr. Edson Okada for collecting biological material and the information they provided. Research supported by CAPES, CNPqPELD, Furnas Centrais Elétricas, and Nupélia (logistic support). 


\section{REFERENCES}

Almada VC, Robalo JI, Levy A, Freyhof J, et al. (2009). Phylogenetic analysis of peri-Mediterranean blennies of the genus Salaria: molecular insights on the colonization of freshwaters. Mol. Phylogenet. Evol. 52: 424-431.

Fernandes-Matioli FMC, Matioli SR and Almeida-Toledo LF (2000). Species diversity and geographic distribution of Gymnotus (Pisces: Gymnotiformes) by nuclear (GGAC)n microsatellite analysis. Genet. Mol. Biol. 23: 803-807.

Gupta M, Chyi YS, Romero-Severson J and Owen JL (1994). Amplification of DNA markers from evolutionarily diverse genomes using single primers of simple-sequence repeats. Theor. Appl. Genet. 89: 998-1006.

Hall TA (1999). BioEdit: a user-friendly biological sequence alignment editor and analysis program for Windows 95/98/ NT. Nucl. Acids Symp. Ser. 41: 95-98.

Haponski AE and Stepien CA (2008). Molecular, morphological, and biogeographic resolution of cryptic taxa in the Greenside Darter Etheostoma blennioides complex. Mol. Phylogenet. Evol. 49: 69-83.

Hilsdorf S, Oliveira C, Lima FCT and Matsumoto CK (2008). A phylogenetic analysis of Brycon and Henochilus (Characiformes, Characidae, Bryconinae) based on the mitochondrial gene 16S rRNA. Genet. Mol. Biol. 31: 366-371.

Izel ACU, Pereira-Filho M, Melo LAS and Macedo JLV (2004). Evaluation of dietary protein contents for juvenile matrinxã (Brycon cephalus). Acta. Amazon. 34: 179-184.

Kawamura K, Yonekura R, Katano O, Taniguchi Y, et al. (2009). Phylogeography of the bluegill sunfish, Lepomis macrochirus, in the Mississippi River Basin. Zoolog. Sci. 26: 24-34.

Kocher TD, Thomas WK, Meyer A, Edwards SV, et al. (1989). Dynamics of mitochondrial DNA evolution in animals: amplification and sequencing with conserved primers. Proc. Natl. Acad. Sci. U. S. A. 86: 6196-6200.

Lima FCT (2003). Subfamily Bryconinae (Characins, Tetras). In: Checklist of the Freshwater Fishes of South and Central America (Reis RE, Kullander SO and Ferraris CJ Jr, eds.). EDIPUCRS, Porto Alegre, 174-181.

Lima FCT (2004). Brycon gouldingi, a new species from the rio Tocantins drainage, Brazil (Ostaiophysi: Characiformes: Characidae), with a key to the species in the basin. Ichthyol. Explor. Freshwat. 15: 279-287.

Machado ABM (2005). Lista da Fauna Brasileira Ameaçada de Extinção: Incluindo as Espécies Quase Ameaçadas e Deficientes em Dados. Fundação Biodiversitas, Belo Horizonte.

Maltagliati F, Lai T, Casu M, Valdesalici S, et al. (2006). Identification of endangered Mediterranean cyprinodontiform fish by means of DNA inter-simple sequence repeats (ISSRs). Biochem. Syst. Ecol. 34: 626-634.

Margarido VP and Galetti-Junior PM (1999). Heterochromatin patterns and karyotype relationships within and between the genera Brycon and Salminus (Pisces, Characidae). Genet. Mol. Biol. 22: 357-361.

Miller MP (1999). Computer note. MANTEL-STRUCT: a program for the detection of population structure via Mantel tests. J. Hered. 90: 258-259.

Monesi N, Jacobs-Lorena M and Paco-Larson ML (1998). The DNA puff gene BhC4-1 of Bradysia hygida is specifically transcribed in early prepupal salivary glands of Drosophila melanogaster. Chromosoma 107: 559-569.

Neto MSS, Alves R, Figueiredo AC and Hino K (1993). Caracterização hidrogeoquímica da bacia do rio Manso-Cuiabá, Mato Grosso. Acta Limnolog. Bras. 6: 230-244.

Pazza R, Kavalco KF, Prioli SMAP, Prioli AJ, et al. (2007). Chromosome polymorphism in Astyanax fasciatus (Teleostei, Characidae), Part 3: Analysis of the RAPD and ISSR molecular markers. Biochem. Syst. Ecol. 35: 843-851.

Posada D and Crandall KA (1998). MODELTEST: testing the model of DNA substitution. Bioinformatics 14: 817-818.

Prioli SMAP, Prioli AJ, Julio HF Jr, Pavanelli CS, et al. (2002). Identification of Astyanax altiparanae (Teleostei, Characidae) in the Iguaçu River, Brazil, based on mitochondrial DNA and RAPD markers. Genet. Mol. Biol. 25: 421-430.

Reeves RG and Bermingham E (2006). Colonization, population expansion, and lineage turnover: phylogeography of Mesoamerican characiform fish. Biol. J. Linn. Soc. 88: 235-255.

Schlüter PM and Harris SA (2006). Analysis of multilocus fingerprinting data sets containing missing data. Mol. Ecol. Notes 6: 569-572.

Schulz HK, Śmietana P and Schulz R (2004). Assessment of DNA variations of the noble crayfish (Astacus astacus L.) in Germany and Poland using Inter-Simple Sequence Repeats (ISSRs). Bull. Fr. Pêche Piscic. 372-373: 387-399.

Swofford DL (2002). PAUP: Phylogenetic Analysis Using Parsimony and other Methods. Version 4. Sinauer Associates, Inc. Publisher, Sundeland.

Tamura K, Dudley J, Nei M and Kumar S (2007). MEGA4: Molecular Evolutionary Genetics Analysis (MEGA) software version 4.0. Mol. Biol. Evol. 24: 1596-1599. 